\title{
Chapter 2 \\ Baby (Not So) Friendly: Implementation of the Baby-Friendly Hospital Initiative in Serbia
}

\author{
Ljiljana Pantović
}

\section{Introduction}

Diši! Diši!'Ajmo sad, gurajte glavica samo što nije!

Breath! Breath! Let's push now the head is almost here!

During my fieldwork in one of the largest maternity hospitals in the Balkans, with over 6000 births per year and 20-25 births per day, these were the most frequently uttered sentences in the delivery ward. When the baby is born, it is "not like in Hollywood movies, where you hear crying instantly', said Sandra, a new mother describing her birthing experience. She went on to tell me that: 'the seconds you wait before the baby takes its first breath feel like hours'.

'Don't worry, baby needs a moment to get their bearings'. Mara, ${ }^{1}$ the nursemidwife, comforts Sandra as she suctions the baby's nose and swiftly and with such dexterity cuts and ties the umbilical cord. The baby is not on Sandra's chest while Mara is completing these procedures but on the edge of the gynaecological bed. Sandra's husband is not there; he is home waiting for Sandra to be allowed to turn

\footnotetext{
${ }^{1}$ All names and other personal identifiers in the chapter have been changed to protect privacy and confidentiality.
}

\begin{abstract}
This research was supported by the Klinzing Grant for Dissertation Research, European Studies Centre, University of Pittsburgh, Social Sciences Doctoral Dissertation Fellowship, University of Pittsburgh. This article was realised with the support of the Ministry of Education, Science and Technological Development of the Republic of Serbia, according to the Agreement on the Realisation and Financing of Scientific Research.
\end{abstract}

\footnotetext{
L. Pantović $(\bowtie)$

Institute for Philosophy and Social Theory, University of Belgrade, Belgrade, Serbia e-mail: 1jiljana.pantovic@instifdt.bg.ac.rs
} 
her phone back on so she can call him with the good news. The baby starts to cry and Mara hands the baby over to Sandra.

Sandra was right, those seconds feel like hours, while the time the baby spends on the mother's chest, between 1 and $3 \mathrm{~min}$, passes in a heartbeat. 'Congratulations! Here is your baby. Look here, ten fingers and ten toes. What is the baby's name?' said Mara. 'Can you please repeat to me the number on your wristband?' she asks Sandra. This is a scripted conversation for Mara that she has done too many times to count.

It was a routine that I witnessed more than a hundred times during the births that I attended during my fieldwork in the hospital. Mara asks these questions to make sure there are no mistakes in the moments when the baby and mother are separated. It is not a question of if they will be separated, but when. Sandra repeats the number on her wristband to Mara while simultaneously trying to take her first look at the child she has been carrying in her body all these months. There is no discussion of breastfeeding, it was not a part of Mara's script. 'Is that the same number as the number we just gave baby? Can you tell us that number?', asks Mara again.

I started a timer on my watch when the baby was given to Sandra and observed the same routine pattern. In less than $3 \mathrm{~min}$, the baby is taken from the mother's arms, weighed and measured, and put under the heater on the table on the far wall of the delivery cubicle. The mother is encouraged to stay on the delivery bed and rest. She is given her cell phone back so she can call her partner and family to tell them the birth went well. Partners and other family members are not allowed in the hospital and will only see both mother and child in 2-4 days' time when they are discharged from the hospital.

Most of the time, the newborns cry while under the lights until they tire themselves out. Mother and baby stay like this, in the same space but too far apart to see each other for another 1-2 h. The mother is waiting for the placenta to be delivered, to be inspected by the doctor and to have her episiotomy sewn up, and having her blood pressure measured every $30 \mathrm{~min}$. After those $2 \mathrm{~h}$ pass and both mother and child are in good health, the baby is put back into the mothers' arms. In a wheel bed, the pair are taken downstairs to the 'bejbifrendli' ward on the first floor of the hospital. There they will be rooming in with at least one but as many as three more babies and mothers for the remainder of their time in the hospital.

This is what a typical birth and hospital stay look like for most mothers in maternity hospitals in Serbia that once were certified by the WHO/UNICEF BabyFriendly Hospital Initiative (BFHI). When I asked Mara why this hospital was not following all the steps prescribed by the initiative, she stated: 'Oh, we are following them. We must adapt them a little. International standards get a bit fuzzy here'. At the centre of this chapter is the following question: What does being a Baby-Friendly Hospital look like in practice?

I show the important insight ethnography provides in understanding the implementation and evaluation of the global Baby-Friendly Hospital Initiative (BFHI) in the context of the European semi-periphery. In Serbia today, less than $13 \%$ of children are exclusively breastfed for the first 6 months of life (Ministry of Health, 2018). And yet, Serbia has officially been a part of the BFHI for over 26 years. We 
know little about why Serbia's implementation of the BFHI has been so challenging. There is little, current published literature on the implementation of the BFHI in Serbia or breastfeeding more generally. During the almost 30-year period since the BFHI was adopted in Serbia, there was one external evaluation (Becker \& Zisovska, 2009) of the country's BFHI implementation process; however, it was conducted over 10 years ago and failed to take into account the local socio-political context under which this initiative had been implemented. Without understanding these contexts, one cannot fully appreciate why the initiative had only moderate success in the country or propose effective solutions.

I combine analysis of global BFHI policy with a historical overview of the sociopolitical context in which it was implemented and ethnographic observations to show that in Serbia the global BFHI has been 'thinly' implemented. It has not had substantive buy-in from healthcare workers in maternity hospitals, nor has it resulted in significant changes in the routines on the hospital floor that would positively promote and support breastfeeding. Despite a renewed national-level commitment to breastfeeding promotion, the policies are still thinly learned and implemented.

The global Baby-Friendly Hospital Initiative implemented in Serbia in the early 1990s and the national-level policies which renewed it in 2018 have been constrained by social, political and economic conditions that hindered the uptake of the program by frontline health workers - namely the devastating effects of the civil war and international sanctions in the 1990s, and the deleterious effects of IMF policies on the Serbian healthcare system since the 2000s. I suggest that the pressure of time due to high workloads, and understaffed hospitals, in combination with unsustainable national funds for implementation may contribute to the reality of the thin implementation of BFHI.

After describing my research methods, I briefly present the key tenets of the global BFHI. I then address some of the key policy literature on the initiative and breastfeeding more generally. I describe three key socio-political periods from 1994 through to the present that have impacted the BFHI and health care more broadly in Serbia. I then juxtapose this review of the published literature and policy documents with my observations of the lack of internalisation of the ten steps of the BFHI visible in the everyday routines of one maternity ward.

\section{Methods}

My analysis of the BFHI is based on a year of ethnographic fieldwork conducted during 2016-2017 in a large city in Serbia as part of a larger research project on maternal health care (Pantovic, 2016, 2018, 2019). I spent 4 months of participant observation in one of the largest maternity hospitals in Serbia, observing over 150 births, and 8 months in birthing classes taught by nurse-midwives. Inside the hospital, I shadowed various doctors, mostly residents, three to four times a week to learn what their typical workday was like. I was there to give a supportive smile to the women during delivery, and to help out the nurses when they made gauze and other 
materials. I took the first pictures of newborns so their mothers could share them with their families and partners. I made and drank coffee with the medical staff, and in general, I spent time observing the daily routines in the ward. I conducted semistructured interviews with 14 gynaecologists and with 80 women who had given birth during that year, and unstructured interviews with four nurse-midwives and three owners and non-medical staff of privately-owned institutions, centred on maternal care. I also analysed relevant documents, including policies and reports on maternity care in Serbia. The transcribed interviews and field notes were entered into qualitative research NVivo software for managing, analysing and interpreting the data. The data were analysed using a mixture of deductive and inductive codes. Since this chapter is based on a larger study on privatization and consumerism of maternal health care, initially the data were analysed based on deductive codes focusing on patient provider relationships, continuity of care and birthing experiences. What emerged out of my field notes and interviews were inductive codes around breastfeeding, skin-to-skin contact in the delivery ward and working conditions in the maternity hospital. These inductive themes form the centre of the data presented in this chapter.

\section{The Global Baby-Friendly Hospital Initiative}

In 1991, due to a decline in breastfed children across the world, the WHO and UNICEF launched the Baby-Friendly Hospital Initiative. The momentum behind the initiative was a long-standing grassroots movement that became prominent in the 1970s; the movement was fuelled, in particular, by a call by North American mothers to boycott baby formula sold by big corporations such as Nestle, who had been producing infant foods since the start of the twentieth century (Van Esterik, 2006). Their lobbying was successful and lead to the creation of the 1981 International Code of Marketing of Breast Milk Substitutes (WHO, 1981) which discouraged the advertising and privileging of formula over breast milk. WHO and UNICEF published the Ten Steps to Successful Breastfeeding in 1989, as part of a set of policies and procedures for maternity facilities to implement in order to support and improve breastfeeding. In 1990, the Innocenti Declaration On The Protection, Promotion and Support of Breastfeeding called for all governments to implement the ten steps within their maternity and newborn programs. The BabyFriendly Hospital Initiative, launched by WHO and UNICEF in 1990, is a set of guidelines intended to motivate facilities worldwide to implement the Ten Steps to Successful Breastfeeding and comply with the International Code of Marketing of Breast-milk Substitutes (WHO, 2017).

1a. Comply fully with the International Code of Marketing of Breast-milk Substitutes and relevant World Health Assembly resolutions.

1b. Have a written infant feeding policy that is routinely communicated to staff and parents.

1c. Establish ongoing monitoring and data-management systems. 
2. Ensure that staff have sufficient knowledge, competence and skills to support breastfeeding.

3. Discuss the importance and management of breastfeeding with pregnant women and their families.

4. Facilitate immediate and uninterrupted skin-to-skin contact and support mothers to initiate breastfeeding as soon as possible after birth.

5. Support mothers to initiate and maintain breastfeeding and manage common difficulties.

6. Do not provide breastfed newborns any food or fluids other than breast milk, unless medically indicated.

7. Enable mothers and their infants to remain together and to practice rooming-in 24 hours a day.

8. Support mothers to recognize and respond to their infants' cues for feeding.

9. Counsel mothers on the use and risks of feeding bottles, teats and pacifiers.

10. Coordinate discharge so that parents and their infants have timely access to ongoing support and care.

The Baby-Friendly Hospital Initiative was meant to not only promote breastfeeding but also to empower women to feel confident in this process. The BFHI focuses on reforming maternity care institutions and educating medical providers, and the wider community to support breastfeeding. For a hospital to receive the status of 'baby-friendly', the staff must be educated on the benefits of breastfeeding and the risks associated with supplementary bottle feeding. Promoting or advertising formula is banned in baby-friendly hospitals. The hospital has to provide rooming-in for mother and infant and enable breastfeeding on demand starting with the newborn latching on within the first hour after birth (WHO/UNICEF, 2009). Women have to be educated about breastfeeding as well and have access to lactation specialists to support them in using breastfeeding techniques (WHO, 2017).

Several studies have shown that hospitals that are BFHI-accredited have higher breastfeeding rates than hospitals that do not or have not been renewed (Bartington et al., 2006; Abolyan, 2006; Bagci Bosi et al., 2016; Pérez-Escamilla, Martinez \& Segura-Pérez, 2016; Braun et al., 2003). However, policy analyses report 'babyfriendly fatigue' in various countries - a term used to describe the waning interest in the initiative at the national level (2017). WHO (2017) estimates that only about $10 \%$ of babies in the world are born in a facility currently designated as baby friendly.

Public health and anthropological studies that examine the implementation of global breastfeeding texts such as the BFHI identify a number of challenges. Anthropological studies in particular demonstrate the social and cultural distance between the producers of global guidelines and their recipients, outlining how global texts misalign with local realities, including the contexts and needs of mothers and frontline workers (Dykes, 2006; Desclaux \& Alfieri, 2015; Blystad et al., 2010; Gottschang, 2000). Ethnographic accounts of the implementation of breastfeeding policies focus on how the process of breastfeeding has been undermined by capitalist regimes. This includes the negative impacts of the influences of industrialisation and medicalisation on post-natal wards, which shape the use of time and space, and decisions surrounding infant feeding (Dykes, 2006) and the reinforcement of inequities in the division of labour, gender roles and power relations through 
breastfeeding discourses communicated by the public and in health promotion literature (Maher, 1992; Faircloth, 2013; Tomori, 2014; Stearns, 2009; Haraway, 2013). Numerous studies have traced the disconnect between specific WHO infant feeding guidelines and the way breastfeeding is actually experienced as a culturally and socially embedded practice (Desclaux \& Alfieri, 2015; Blystad et al., 2010; Gottschang, 2000). Desclaux and Alfieri (2015), for instance, argue that HIVpositive women in West Africa did not apply medical recommendations regarding infant feeding since none of the infant feeding practices recommended were common in the lay culture of feeding. Similarly, Gottschang (2000) examines the conflict between global BFHI guidelines and local realities for Chinese mothers whose economic realities make breastfeeding difficult.

Numerous public health studies also identify challenges that negatively impact the implementation of the BFHI. At the national level, funding constraints are a major barrier (Saadeh, 2012; UNICEF \& WHO, 2017). The 2nd Global Nutrition Policy Review, implemented by WHO in 2016-2017, a multi country evaluation of the implementation of the BFHI, notes that with the exception of a few countries, sustainable national funding for BFHI implementation is rare. In many settings, the initiative was funded from government or other sources when it was initiated; however, due to various issues, including changes in national leadership, shifting national priorities or tight budgets, funding is no longer available (UNICEF \& WHO, 2017). The BFHI works best when it is endorsed and funded by national authorities; however, there is often low awareness or acceptance of the need for the initiative among government departments and, as a result, government ownership of the initiative can be lacking (Wieczorek et al., 2015; Saadeh, 2012; UNICEF \& WHO, 2017). In countries where the BFHI has been less successful, government ownership is often less compared to the ownership demonstrated by external bodies such as donors and NGOs (UNICEF \& WHO, 2017).

National funding constraints often trickle down to the facility level, where there is a lack of resources for the assessment and designation process, or for training staff (UNICEF \& WHO, 2017). Even where funding and national political coordination exists, the individual experiences and attitudes of health workers and hospital management are also important issues influencing the implementation of the BFHI (Wieczorek et al., 2015; Nickel et al., 2013; Abolyan, 2006; UNICEF \& WHO, 2017; Walsh et al., 2011). The attitudes of administrators influence the commitment of health workers to implement the steps (Nickel et al., 2013; Schmied et al., 2011; Wieczorek et al., 2015). For instance, some studies describe the action of an individual change agent, who facilitates implementation of the steps by promoting the initiative among managers of professional groups and units, requiring staff to participate in hands-on breastfeeding trainings, and including breastfeeding support in staff members' annual performance reviews (Nickel et al., 2013; Wieczorek et al., 2015).

Misunderstanding of the BFHI on the part of health workers can also pose a challenge to BFHI implementation (Abolyan, 2006; Nickel et al., 2013; UNICEF \& WHO, 2017; Walsh et al., 2011; Wieczorek et al., 2015). For instance, in North Carolina, night shift nurses thought that supplemental artificial feeds had few if any 
negative consequences, and felt that providing the mother an opportunity to rest (by removing the baby) was more beneficial than supporting breastfeeding (Nickel et al., 2013). Rather than using the BFHI as a strategy to improve health professionals' practices, nurses in Australia tended to 'focus on the ten steps as a set of tasks to be accomplished' (Schmied et al., 2011, p. 9). They interpreted the BFHI as a tool to convey the message that breastfeeding was the only way to properly feed a baby and then used it to influence infant feeding decisions, giving women little choice in their feeding method (Schmied et al., 2011).

Systemic issues, including a high workload for health facility staff and their lack of time, have also been identified as causes of the thin implementation of the BFHI (Reddin, Pincombe \& Darbyshire, 2007; Taylor et al., 2011; Schmied et al., 2011; Semenic et al., 2012; Thomson et al., 2012; Nickel et al., 2013; Abolyan, 2006). In some contexts, health workers often perceive the BFHI in a positive way and are committed to BFHI implementation, but the pressure of time leads them to take shortcuts or seek a 'quick fix'. In Serbia, the BFHI has been constrained by social, political and economic conditions that hindered the commitment to the program at the national level as well as its uptake by facilities and frontline health workers.

\section{The History of the Baby-Friendly Hospital Initiative in Serbia}

I describe three key socio-political periods that impacted the BFHI and health care more broadly in Serbia: the 1990s, early 2000s and the current political regime from 2012 onwards. Larger social, economic and political contexts shape the implementation of global maternal health policies; my descriptions of these three periods provide crucial historical context, shedding important light on the low prioritization of the BFHI at the national level, and its thin implementation in health facilities.

\section{The 1990s}

During the 1990s, Serbia was under international isolation. The wars and international sanctions left the previously 'generous' healthcare sector of Yugoslavia in severe crisis (Perišić, 2014). The Milošević regime tried to maintain the illusion of the status quo, but in reality, the country's infrastructure was deteriorating (Perišić, 2016). All of the hospitals in Serbia lacked basic supplies, and medical staff experienced significant delays in receiving their salaries (Stambolovic, 2003). The last decade of the twentieth century was a harsh one for Serbian citizens. The old millennium ended with the 1999 NATO bombing campaign that devastated the country. One of the gynaecologists I spoke to remembers working in a large maternity hospital during the sanctions and the bombing: 
During the sanctions, it became increasingly difficult to work. There were no medications, no resources. During the bombing, it was the worst. We would frequently lose electricity. Imagine doing a C-section under candlelight! No one did this except us! We worked, without water or power but we worked.

Milošević's regime led the country into sanctions and 'had taken Serbia from the largest republic in the internationally respected and cosmopolitan Socialist Federal Republic of Yugoslavia to a pariah country plagued by nationalism, haunted by war crimes, and devastated by economic insecurity' (Greenberg, 2014, p. 5). It was during this period of upheaval that the country formally adopted the WHO BabyFriendly Hospital Initiative with the aim of ameliorating the low rates of breastfeeding and high mortality rate of infants and young children (Chalmers, 1997). When Becker and Ziskova's (2009) evaluation came out, Dr. Durda Kisin from the Public Health Institute in Serbia stated that 'this initiative was implemented in a time when most hospitals did not have running hot water. The idea was to encourage mothers to breastfeed, but the times were tough' (RTS. Problemi u srpskim porodilištima 2010 , translated by the author).

\section{The Early 2000s}

The new century brought about a feeling of hope and change in Serbia that could have led to a better implementation of the policy than the previous period. People stormed the nation's capital of Belgrade on 5 October 2000 and ousted Milošević. The new democratically-elected Serbian government had high hopes for overall change. The new post-Milošević government slowly managed to lift the international sanctions and started negotiations of their own with the International Monetary Fund (IMF). The goal of the post-Milošević government was to 'create a real market economy' (Perišić, 2016, p. 649), emphasizing market and economic stability. When it came to reforms in health care, this government tried to maintain at least the perception of universal healthcare coverage. The government sought help from various international aid organisations to re-build essential healthcare infrastructure. Most notably, the World Health Organization (WHO) and the World Bank provided humanitarian aid to Serbian hospitals, with special attention to the maternity wards. At this time, the UNICEF country office was still providing support for the implementation of the BFHI Initiative (Becker \& Zisovska, 2009, p. 41). As of 2005 , the largest number of public maternity wards and hospitals, $84 \%$, were certified as baby-friendly (Ministry of Health, 2018). At this time, $91 \%$ of women were breastfeeding exclusively upon discharge in Baby-Friendly designated facilities and $78 \%$ of births were taking place in facilities certified as meeting and maintaining Baby-Friendly criteria (Becker \& Zisovska, 2009).

Even though hopes were high right after the revolution in Serbia, they quickly grew into disappointment. Along with the rest of the world, Serbia felt the impact of the 2007/2008 global economic crisis that shattered the already fragile and still recovering economy. In this period, the WHO and UNICEF officially stopped 
funding the BFHI and national public health officials noted a drop in children exclusively breastfed in the first 6 months of life, from $15.1 \%$ to the current $12.8 \%$ (Ministry of Health, 2018). It is unclear if the national government provided any funding for the BFHI afterwards. Still recovering from the wars and sanctions, at this time the International Monetary Fund imposed reforms that have had a severe impact on healthcare provisioning (Perišić, 2014, 2016; Stambolieva, 2016). Every one of these reforms hurt healthcare provisioning for most of the population of Serbia. These reforms included further containing public healthcare spending and imposing a cap on the duration of sick leave benefits, increasing the level of copayments, and downsizing the number of medical and nonmedical staff in public health care, as well as speeding up reforms of public enterprises and the privatization process. Reforms also included severe cuts in public healthcare funding and imposition of a ban on new hires within the public sector by the right-wing government, at the time led by then Prime Minister (now President) Aleksandar Vučić. While there are no official reports as to how many public healthcare providers have immigrated to Western European countries, the public and media narrative describes the current state of the Serbian healthcare system as on the brink of collapse (Arsenijevic, Pavlova \& Groot, 2013; Hyde, 2016; Vasiljevic-Prodanovic, 2015).

As Becker and Zisovska note, BFHI designations have an expiration date, and only half of the initially awarded hospitals were re-appraised in the period between 2002 and 2010 (Ministry of Health, 2018). By 2009 most of the hospitals no longer met the standard (Becker \& Zisovska, 2009). On behalf of UNICEF and WHO, in 2009, Becker and Zisovska carried out an evaluation of the BFHI from 1995 to 2008. Drawing on interviews with managers, health workers and mothers, observations, and desk review, the aim of the evaluation was to assess the status of the initiative and provide guidance and recommendations to the newly formed government working group for BFHI (Becker \& Zisovska, 2009). Becker and Zisovksa (2009, p. 25) concluded that the initiative was supported by the national government but that the program itself was only 'moderately effective until about 2003 when support was reduced and activity curtailed, though low-level activity continued in some areas due to the commitment of individuals'. They reported that the current practices in the observed hospitals were well below the standards expected by $\mathrm{WHO} /$ UNICEF global criteria, and noted that there 'are misperceptions of what the BFHI is by many mothers, staff, and managers as well as the wider community' (Becker \& Zisovska, 2009, p. 2). Hospital staff, as well as mothers, had limited knowledge on the benefits of the BFHI practices, only that it should be done, and women and providers equated the entire initiative with step seven: the rooming-in recommendation. Women were left to care for their babies on their own without any education or support on breastfeeding. Both managers and staff often misunderstood whether their facility was actually accredited (Becker \& Zisovska, 2009). The low activity and low profile of the BFHI was attributed both to lack of funds for national coordination and local implementation (Becker \& Zisovska, 2009). In accordance with the recommendation given in the Becker report in 2009, a National Committee on Breastfeeding was formed (Ministry of Health, 2018). 


\section{2 to the Present}

From 2012 onwards, the Serbian government has made several attempts to revive the BFHI, but these attempts have been unsystematic, hard to document and follow up on and have resulted in little to no actual change. In 2012 and 2013, the public Institute for the Care of Mothers and Children conducted training with 600 medical providers, educating them on infant nutrition (Ministry of Health, 2018). But adherence to standards that encourage breastfeeding was not mandatory in the new accreditation process of public hospitals. As it stands, not one of the previously certified Baby-Friendly hospitals has gotten its status re-confirmed (Ministry of Health, 2018). The program did not continue, nor was there follow up from either the government or UNICEF (Ministry of Health, 2018).

In June 2017, Ana Brnabić became the first woman and the first openly gay prime minister. After her appointment, Brnabić's government set up the National Program to Support Breastfeeding (2018). This program is very self-critical of the current disconnect between the practice and policy, stating in its opening paragraph that: 'the Republic of Serbia has a legal and policy framework around breastfeeding but it is not implemented to the fullest extent' (Ministry of Health, 2018, p. 4).

The national program makes a clear link with the global BFHI and notes the importance of this initiative for maternal care in Serbia (Ministry of Health, 2018, p. 5). The program explicitly states the importance of implementing the Ten Steps in every maternity ward and hospital in Serbia (Ministry of Health, 2018, p. 27). The policy actively supports the idea that mothers and newborns should not be separated during their stay in the hospital along with a list of other 'shoulds' - for maternity hospitals and wards (Ministry of Health, 2018). For example, the hospitals should provide individualised care, should be family-oriented, partners should be present at birth, the first feeding should happen in the first hour of birth, there should be skin-to-skin contact. The program sums up this list of shoulds by stating that it is the state's job to 'support mothers so that they find breastfeeding as a pleasant and useful experience and not a chore and a norm they have to fulfill' (Ministry of Health, 2018, p. 6). As a precursor to the new national program, the Serbian government in 2017/2018, with the support of UNICEF, conducted another round of BFHI training for medical providers (Ministry of Health, 2018), although there is no indication of how many providers were trained and where these providers work. A major insight that ethnography offers for health policymakers is that it can offer an in-depth understanding of what happens in health facilities, and what gets lost when moving from policy to practice. I now turn to my own ethnographic research in one previously accredited Baby-Friendly Hospital in Serbia. 


\section{The Not-So-Baby-Friendly Maternity Hospital}

Mothers who gave birth vaginally are now rooming in with their newborns, in accordance with the seventh step for the promotion of breastfeeding. This roomingin $\underline{i s}$ the hospitals' baby-friendly approach. This 'bejbifrendli' ward consists of around 20 rooms. The rooms have either four or two beds. Each room has a toilet and a shower but sadly not all the rooms' lavatories are functional, so women tend to share and walk to the rooms that do have a working shower and toilet.

Along with sharing the room with at least one another woman, mothers in the bejbifrendli ward also room in with their newborns in small cribs that are placed right next to their beds. In the entire hospital, there are no railings. After giving birth, which usually also includes having an episiotomy, women tend to use the crib itself as support to get up in order to get out of bed to pick up their babies or walk to the closest bathroom. Visitors are not allowed in the bejbifrendli ward, or in any area of the hospital. This means that the women are completely isolated during their stay from their partners, their family or any kind of support system. The lack of internalization of the Ten Steps is visible in the everyday routines in this ward.

When both women and medical providers use the English term 'bejbifrendli' what they are referring to is a ward in the maternity hospital where mothers who had given birth vaginally are placed right after delivery. Women who had C-sections are not in this 'bejbifrendli' ward, they spend the first night in the intensive care ward and the next 3-4 days in the semi-intensive care ward. The $\mathrm{C}$-section newborns are not with their mothers during their stay in the hospital. The $\mathrm{C}$-section ward mothers see their newborns on a fixed feeding schedule of every $3 \mathrm{~h}$. This was the standard in the entire hospital after the BFHI accreditation.

The nurses would bring the newborns to the mothers on a 3-h cycle for around $30 \mathrm{~min}$. Before giving the babies to their mothers the nurses would weigh them. Mothers were told to feed their babies for 5 min on each breast, burp the baby and hand them back to the paediatric nurse. After feeding the baby would be weighed again and if the nurse deemed that the baby was not fed enough, they would give them baby formula.

In the bejbifrendli ward of the hospital, women were meant to take care of their infants on their own, including feeding them. But this did not mean they could do whatever they wanted, including breastfeed on demand. Ana was a third-time mother who took the time to inform herself about UNICEF's breastfeeding policies because of her previous birth experiences in the hospital. After her discharge from the hospital, she told me about the nurses' lack of support for her wish to breastfeed on demand.

Having breastfed before, Ana, unlike other women who had just given birth for the first time, had enough hands-on experience when it came to breastfeeding and she felt confident in her ability to care for her baby on her own during her stay in the baby-friendly ward. She wanted to breastfeed her baby more frequently than what women are typically instructed to do during the maternity classes they can attend prior to giving birth. In the classes, women are told that they should feed babies, not 
on demand but on a 3-h schedule and no more than 5 min per breast. Her breastfeeding more than those prescribed 10 min created problems within the babyfriendly ward.

\begin{abstract}
I had a bad experience with breastfeeding in the hospital. I was in the baby-friendly ward, the baby was with me. One nurse noticed I wasn't breastfeeding my child during the hospital prescribed time frame but whenever I wanted. She kept telling me that I should not feed the baby whenever I wanted to, that the baby needs time to digest the milk. She told me that I should feed the baby for no more than 5 minutes. I did not want to argue with her, so I said, fine. She saw that I wasn't really going to listen to her really. She sent another nurse in with a stopwatch and she timed me! After five minutes past, she took the baby and placed him on my other breast. After another five minutes, she took him and put him in the crib. I had to secretly breastfeed my child. I was so nervous. I requested a breast pump because I had so much milk and the nurse told me it was my own fault for not listening to their rules. They are supposed to support breastfeeding but not like this.
\end{abstract}

Ana was one of the few mothers who had attended birthing classes in order to prepare for labour psychologically and physically. These classes are completely free and are covered through the state health insurance. It is during these classes that breastfeeding is discussed the most with pregnant women. These courses are the key sites where women are encouraged to breastfeed, and yet, according to the main coordinator of the classes, less than $30 \%$ of the women in the city actually attend these courses because they live too far or have to work during class times.

During the classes that I observed, the quality of information about breastfeeding provided to women varied and depended solely on the attitude and knowledge of the teaching-midwife. Nurse-midwives would always list the medical benefits of breastfeeding from these studies, such as lower rates of middle ear infections, lower cancer rates and other benefits. However, in addition to being told that babies should not be fed on demand, instructors would frequently add claims about the benefits of breastfeeding that were harder to support. For example, during one such lecture, a nurse-midwife told her class that: 'you won't gain weight if you breastfeed and your child won't become a drug addict (narkoman)'. A key aspect of the BFHI is teaching medical providers about the medical benefits of breastfeeding for both mother and infant. Yet, when I conducted fieldwork during 2017 there was no mention of or discussion on these trainings in staff meetings.

Feeling safe and supported is a key prerequisite for women to feel empowered to successfully breastfeed (Stankovic, 2017). This support should also entail providing women with ample and adequate information about their birth, breastfeeding, and other concerns, as well as respecting their privacy and wish to rest after giving birth. When asked about breastfeeding support, women replied that their experiences with the staff varied drastically. 'When I just got to the room the nurse was great. She explained things to me and even helped me place the baby properly. The nurse that came in the afternoon shift, she did not even bother' said one woman while trying to soothe her crying newborn. On many occasions I observed that instead of a nurse coming in to help with the first feeding, women were played an old VHS tape about breastfeeding. This appeared to be a WHO breastfeeding video from the 1990s. It was in English with Serbian subtitles. What usually would happen is that the nurse 
would turn the video on and leave the room. The moment the nurse left, the mothers would show no interest in watching this old video. Some even told me that they looked up how-to tutorials on YouTube rather than watching the VHS, or that they asked for help from their roommate if they were lucky enough to have a roommate who had given birth before.

It would be unjust and a simplification to state that nurses refuse to provide mothers with lactation assistance. That their refusal to teach and encourage women to breastfeed was a matter of active resistance towards the policy and that they do not see the benefits of breastfeeding. We cannot disregard the global and local political and economic constraints that affect their agency as healthcare workers. As described in the background section, there have been radical cuts in Serbia's healthcare sector resulting in shortages of staff, especially gynaecological and paediatric nurses, who are tasked with helping women in the recovery process after giving birth.

The nurse-midwives, along with the residents, were the health workers I spent the most time with in the hospital. Most of the midwives were middle-aged women, and all of them can best be described as women who will not tolerate nonsense. The midwives have their break room within the delivery ward. They would usually make coffee for each other and share a breakfast of burek, a type of meat or cheese pie, or some other pastry from the bakery or canned sardines. The conversations in the room were often very lively and jovial, however, the women also frequently used break time to vent about the difficult working conditions they faced in the hospital, especially being overworked and underpaid. While making herself a cup of coffee, one nurse-midwife, Milana, a serious woman with short blond hair, started talking about her feelings about her work.

It is a hard job, but I love it. The only thing I can complain about is the fact that they cut down our off days. We work 12-hour shifts, plus night shifts twice a month (24h shift) and we used to have three days off; now we have two. That is barely enough for you to get some sleep, not nearly enough time if you have a family as well.

The nurse-midwives I spoke to were all very unhappy with their economic status. I asked Nena, another senior midwife, to compare, in her view, their situation during socialism and now; she said: 'Sure the technology is better now, but our paycheck is not. It is challenging to make ends meet let alone think about things like holidays. Those are luxuries for us'. Milena smirked at that comment and added: 'I am surprised we do not make more mistakes along the way! It is because we are tired! Tired, overworked and severely underpaid'.

During my fieldwork, I observed how the shortage of nursing staff affected women's experiences during their stay in this hospital. Women do not even know the names of the medical staff working in the maternity hospital, the staff do not introduce themselves to the women, nor do they wear name tags. The absence of a friendly, human relationship with the staff, coupled with the poor infrastructure of the hospital left women disappointed with their birthing experience (Arsenijevic, Pavlova \& Groot, 2014; Baji et al., 2017; Sekulic, 2016; Pantović, 2016). Frequently they would tell me that they felt as if they were left to fend for themselves. 
When it comes to breastfeeding, they did not explain anything. This is my first baby and I asked the nurse when I should feed the baby for the first time. She told me I could feed her now if I want to. We did try but she (the baby) was not interested. The nurse told me that the baby will be fine even without breast milk in the first 24 hours, that the baby is not hungry that she will let me know when she is hungry. When I asked her to come and help me, she told me that she is too busy to come that I must figure it out on my own.

All the women I spoke to wanted to breastfeed and tried extremely hard to do so in the hospital. Some, like Ana, persisted and breastfed on demand despite the nurses, while others complied with the unwritten rules of the hospital that told them their child needed to supplement their feeding with formula. When leaving the hospital, the struggle continues. 'People think that I am crazy for still breastfeeding my oneyear-old!' one mother told me during our follow-up interview. Although there are no studies on public perceptions of breastfeeding in Serbia, my conversations with mothers and media reports suggest that there are public misconceptions that also contribute to an environment unsupportive of breastfeeding. For instance, according to a BBC news report (Dojenje na javnom mestu u Srbiji: Beba bira gde i kada će da jede, poručuju mame, 2019) women are often met with negative comments and disdain from the general population when they choose to breastfeed in public.

In the hallways of the baby-friendly ward, there are multiple framed posters outlining the ten steps to successful breastfeeding, posters outlining the importance of breastfeeding in the first 6 months of life. Visually the Baby-Friendly Hospital Initiative was very present in the walls and TV screens of the hospital, but most women did not feel they were informed or encouraged to breastfeed. There was a sharp disconnect between what was written on the walls and in policy documents and what occurred in practice.

\section{Discussion and Conclusion}

Through a review of the history of Serbia's BFHI policy implementation, alongside ethnographic observations of the daily routines in one such designated 'babyfriendly' maternity hospital, this chapter provides insight as to why the implementation of the BFHI in Serbia over the past 30 years has been met with little success. I have described three key socio-political periods that impacted the BFHI and health care more broadly in Serbia (contexts that previous external evaluations of BFHI in Serbia have not fully considered): the 1990s, early 2000s, and the current political regime from 2012 onward. I show that the Baby-Friendly Hospital Initiative implemented in Serbia in the early 1990s and the national-level policies which renewed it in 2018 have been constrained by social, political and economic conditions that hindered the uptake of the programs by frontline health workers - including the devastating effects of the civil war and international sanctions in the 1990s, and the deleterious effects of IMF policies on the Serbian healthcare system since the 2000s.

Dobre (2008) uses the term 'thin learning' to describe how EU policies were adopted in Romania to superficially comply with EU accession without actual 
implementation and governmental reform. In the case of the BFHI the policy also appears to have become thinly implemented instead of actually promoting breastfeeding in a meaningful way. Within health facilities, I observed a non-evidencebased approach when providing information about breastfeeding, a lack of rooming in and initiation of breastfeeding within a half hour of birth, and lack of breastfeeding on demand. My findings are similar to those reported by Becker and Zisovska (2009) in their evaluation, which took place over 10 years ago, suggesting that, despite a renewed national-level commitment to breastfeeding promotion, breastfeeding policies are still poorly implemented, with the lack of internalization of the ten steps of the BFHI visible in the everyday routines of the maternity ward.

Women like Ana were left on their own to care for their babies with little breastfeeding education or assistance. Even though the ward was called 'bejbifriendli' and baby formula is not given out routinely, the practice of breastfeeding every $3 \mathrm{~h}$ for $10 \mathrm{~min}$ describes a more staff-schedule friendly than baby-friendly practice. The rationale for separating mothers with $\mathrm{C}$-section from their infants and feeding infants formula during this period is not clear, but it may have been for the ease of staff in caring for mothers. Allowing for feeding on demand would require restructuring hospital and health worker schedules to fit the needs of each individual breastfeeding woman. Instead, women are disciplined to breastfeed on the demand of the hospital. Based on my observations and interviews with health workers, it seems, as in other contexts, that the pressure of time due to high workloads, and understaffed hospitals (Abolyan, 2006; Schmied et al., 2011; Semenic et al., 2012; Taylor et al., 2011; Thomson, Bilson \& Dykes, 2012) in combination with unsustainable national funds for implementation (Saadeh, 2012; UNICEF \& WHO, 2017) may contribute to the reality of the thin implementation of BFHI in Serbia.

Taking a closer look at the social, political and economic context in which the initiative was first implemented in Serbia, it is not difficult to understand why it has had so many shortcomings. The initiative was first signed during sanctions and civil wars with the infrastructure in shambles - conditions under which it would have been impossible to succeed. The larger social and political backdrop of the timing of the initiative is linked with Serbia's political and economic trajectory towards the European Union; by initially signing on to the BFHI, Serbia may have also been trying to signal its alignment with European norms and standards such as empowering women to breastfeed. Yet, political support for the BFHI appears to have waxed and waned. As in other country contexts (Saadeh, 2012; UNICEF \& WHO, 2017) a consistent source of funding for the initiative has also been a challenge. The period of its initial successes was closely tied with the provision of UNICEF funds, but beyond inconsistent funding from external partners such as UNICEF, the initiative has since never had a consistent source of public funding. Funds have been made available for recent trainings of health providers, however, it is unclear if a consistent source of funds is available for training, and for other activities which are important for the implementation of the BFHI, including for the assessment and designation of facilities (Ministry of Health, 2018; UNICEF \& WHO, 2017).

In the past few years, the state of the public maternity hospitals has become a hot-button issue in the country, due partially to intense media scrutiny. Although 
problems in the maternity hospitals were widely known (Arsenijevic, Pavlova \& Groot, 2014), there exists an unwritten rule that women should not speak about them in public. To counter this silence, a grass roots NGO Majka Hrabrost (Mother Courage) collected online surveys from mothers who delivered infants in one of the maternity hospitals in Serbia between 2000 and 2008. It identified three main problems in Serbian maternity care: poor communication, corruption, and outdated medical protocols that are still in use, such as mandatory enemas upon admission (Arsenijevic et al., 2014). These findings confirm the observations I made during my fieldwork, and have also been noted in a more recent survey conducted by another NGO Centar za Mame (Centre for Moms) (Sloboda Rađanju - rezultati o iskustvima žena na porođaju u Srbiji, 2015). In addition to the lack of support for breastfeeding, women are often simply told to endure the lack of support and lack of agency they experience overall during their birthing experience and stay in the maternity hospitals.

Sadly, Mother Courage is no longer working in Serbia and Centre for Moms seems to be the only viable NGO left working on issues around maternity in the country. New problems seem to be emerging while previous issues remain unresolved. Even though the national program for the support of breastfeeding is now over 2 years into implementation, there is no civil sector oversight or analysis of its effects. Furthermore, the Serbian government passed new legislation that effectively slashed maternity leave and pay for most women in Serbia (Apelujemo da se izmene Zakona o finansijskoj podršci porodici sa decom uključe u novi budžet, 2019; Više od 13.000 mama oštećeno Zakonom o finansijskoj podršci porodici sa decom, 2019). With a lack of civil sector oversight, coupled with the poor working conditions in the hospitals and the overall low public interest in promoting breastfeeding, it is difficult to see how the BFHI in Serbia will move beyond thin implementation focused only on written policy documents and lip service by politicians to actual changes in practice.

\section{References}

Abolyan, L. V. (2006). The breastfeeding support and promotion in Baby-Friendly Maternity Hospitals and not-as-yet Baby-Friendly hospitals in Russia. Breastfeeding Medicine, 1(2), 71-78. https://doi.org/10.1089/bfm.2006.1.71

Centar za Mame. (2019). Apelujemo da se izmene Zakona o finansijskoj podršci porodici sa decom uključe u novi budžet. http://centarzamame.rs/blog/2019/11/06/da-li-su-najavljene-izmenezakona-o-finansijskoj-podrsci-porodici-sa-decom-obecanje-ludom-radovanje/. Accessed 7 Aug 2020.

Arsenijevic, J., Pavlova, M., \& Groot, W. (2013). Measuring the catastrophic and impoverishing effect of household health care spending in Serbia. Social Science \& Medicine, 78(1), 17-25. https://doi.org/10.1016/j.socscimed.2012.11.014

Arsenijevic, J., Pavlova, M., \& Groot, W. (2014). Shortcomings in maternity care in Serbia. BirthIssues in Perinatal Care, 41(1), 14-25. https://doi.org/10.1111/birt.12096 
Bagci Bosi, A. T., Eriksen, K. G., Sobko, T., Wijnhoven, T. M. A., \& Breda, J. (2016). Breastfeeding practices and policies in WHO European region member states. Public Health Nutrition, 19(4), 753-764. https://doi.org/10.1017/S1368980015001767

Baji, P., Rubashkin, N., Szebik, I., Stoll, K., \& Vedam, S. (2017). Informal cash payments for birth in Hungary: Are women paying to secure a known provider, respect, or quality of care? Social Science \& Medicine, 189, 86-95. https://doi.org/10.1016/j.socscimed.2017.07.015

Bartington, S., Griffiths, L. J., Tate, A. R., \& Dezateux, C. (2006). Are breastfeeding rates higher among mothers delivering in Baby Friendly accredited maternity units in the UK? International Journal of Epidemiology, 35(5), 1178-1186. doi: 10.1093/ije/dyl155

Becker, G., \& Zisovska, E. (2009). Evaluation of the Baby-Friendly Hospital Initative in Serbia for the period of 1995-2008. WHO/UNICEF.

Blystad, A., van Esterik, P., de Paoli, M. M., Sellen, D. W., Leshabari, S. C., et al. (2010). Reflections on global policy documents and the WHO's infant feeding guidelines: Lessons learnt. International Breastfeeding Journal, 5(18).

Braun, M. L. G., Giugliani, E. R., Soares, M. E. M., Giugliani, C., de Oliveira, A. P., \& Danelon, C. M. M. (2003). Evaluation of the impact of the Baby-Friendly Hospital Initiative on rates of breastfeeding. American Journal of Public Health, 93(8), 1277-1279.

Chalmers, B. (1997). Changing childbirth in Eastern Europe: Which systems of authoritative knowledge should prevail? In R.E. Davis-Floyd \& C.F. Sargent (Eds.), Childbirth and Authoritative Knowledge: Cross-cultural Perspectives (pp. 263-83). University of California Press.

Desclaux, A., \& Alfieri, C. (2015). Between proscription and control of breastfeeding in West Africa: Women's strategies regarding prevention of HIV transmission. In T. Cassidy \& A. El Tom (Eds.), Ethnographies of breastfeeding: Cultural contexts and confrontations (pp. 125-144). Bloomsbury.

Dobre, A. M. (2008). Designing and justifying regional reforms: Lessons from Romania. Policy \& Politics, 36(4), 587-600. https://doi.org/10.1332/147084408X349783

Marinković, L. (2019, July 21). Dojenje na javnom mestu u Srbiji: Beba bira gde i kada će da jede, poručuju mame. BBC News. https://www.bbc.com/serbian/lat/srbija-48585987

Dykes, F. (2006). Breastfeeding in hospital: Mothers, midwives and the production line. Routledge.

Faircloth, C. (2013). Militant lactivism? Attachment parenting and intensive Motherhood in the UK and France. Berghahn Books.

Gottschang, S. Z. (2000). Reforming routines: A Baby-Friendly Hospital in Urban China. In L. M. Whiteford \& L. Manderson (Eds.), Global health policies, local realities: The fallacy of the level playing field (pp. 265-288). Lynne Rienner Publishers.

Greenberg, J. (2014). After the revolution: Youth, democracy, and the politics of disappointment in Serbia. Stanford University Press.

Haraway, D. (2013). Simians, cyborgs, and women: The reinvention of nature. Routledge.

Hyde, R. (2016). Mixed diagnosis for Serbian health system. The Lancet, 388(10061), 2729-2730. https://doi.org/10.1016/s0140-6736(16)32460-6

Maher, V. (1992). The anthropology of breast-feeding: Natural law or social construct. Routledge.

Ministry of Health, Republic of Serbia. (2018). Uredba o nacionalnom programu podrške dojenju, porodičnoj i razvojnoj nezi novorođenčeta. Službeni Glasnik RS. https://www. pravno-informacioni-sistem.rs/S1GlasnikPortal/eli/rep/sgrs/vlada/uredba/2018/53/1/\%20reg. Accessed 5 Oct 2021.

Nickel, N. C., Taylor, E. C., Labbok, M. H., Weiner, B. J., \& Williamson, N. E. (2013). Applying organisation theory to understand barriers and facilitators to the implementation of baby-friendly: A multisite qualitative study. Midwifery, 29(8), 956-964. doi: 10.1016/j. midw.2012.12.001

Pantović, Lj. (2016). Buying a connection. Private practice in public health care - The case of a Serbian maternity hospital. Anthropology of Eastern Europe Review, 34(1), 25-38.

Pantović, Lj. (2018). Not-so-informal relationships. Selective unbundling of maternal care and the reconfigurations of patient-provider relations in Serbia. Südosteuropa. Journal of Politics and Society, 66(3), 371-391. doi: 10.1515/soeu-2018-0029 
Pantović, Lj. (2019). Private within the Public: Negotiating Birth in Serbia. [Doctoral Dissertation, University of Pittsburgh] Pitt Campus Repository. http://d-scholarship.pitt.edu/35994/

Pérez-Escamilla, R., Martinez, J. L., \& Segura-Pérez, S. (2016). Impact of the Baby-friendly Hospital Initiative on breastfeeding and child health outcomes: A systematic review. Maternal \& Child Nutrition, 12(3), 402-417. https://doi.org/10.1111/mcn.12294

Perišić, N. (2014). Health care system between the state and the market - The case of Serbia. Serbian Political Thought, 2, 193-209.

Perišić, N. (2016). The Serbian welfare state: A transition loser. In K. Schubert, P. de Villota, \& J. Kuhlmann (Eds.), Challenges to European welfare systems (pp. 647-669). Springer.

Reddin, E., Pincombe, J., \& Darbyshire, P. (2007). Passive resistance: Early experiences of midwifery students/graduates and the Baby Friendly Health Initiative 10 steps to successful breastfeeding. Women and Birth, 20(2), 71-76. DOI:https://doi.org/10.1016/j.wombi.2007.04.003

RTS. (2010). Problemi u srpskim porodilištima. https://www.rts.rs/page/stories/sr/story/125/ drustvo/470991/problemi-u-srpskim-porodilistima.html. Accessed 7 Aug 2020.

Saadeh, R. J. (2012). The Baby-Friendly Hospital Initiative 20 years on: facts, progress, and the way forward. Journal of Human Lactation, 28(3), 272-275.

Schmied, V., Gribble, K., Sheehan, A., Taylor, C., \& Dykes, F. C. (2011). Ten steps or climbing a mountain: A study of Australian health professionals' perceptions of implementing the baby friendly health initiative to protect, promote and support breastfeeding. BMC Health Services Research, 11(1), 208.

Sekulic, N. (2016). O kulturi rađanja - istrazivanje o problemu nasilja nad zenama tokom porođaja 2 -/Culture of giving birth: Research on the issue of violence against women during delivery. Sociologija, 58, 260. https://doi.org/10.2298/SOC16S1259S

Semenic, S., Childerhose, J. E., Lauzière, J., \& Groleau, D. (2012). Barriers, facilitators, and recommendations related to implementing the Baby-Friendly Initiative (BFI): An integrative review. Journal of Human Lactation, 28(3), 317-334. doi: 10.1177/0890334412445195

Centar za Mame. (2015). Sloboda Rađanju - rezultati o iskustvima žena na porođaju u Srbiji. http://centarzamame.rs/blog/2015/03/01/sloboda-radanju-rezultati-o-iskustvima-zena-naporodaju-u-srbiji/. Accessed 7 Aug 2020.

Stambolieva, M. (2016). Welfare state transformation in the Yugoslav successor states: From social to unequal. Routledge.

Stambolovic, V. (2003). Epidemic of health care reforms. European Journal of Public Health, 13(1), 77-79. https://doi.org/10.1093/eurpub/13.1.77

Stankovic, B. (2017). Women's experiences of childbirth in Serbian public healthcare institutions: A qualitative study. International Journal of Behavioral Medicine, 24(6), 803-814. https://doi. org/10.1007/s12529-017-9672-1

Stearns, C. A. (2009). The work of breastfeeding. Women's Studies Quarterly, 37(3/4), 63-80.

Taylor, C., Gribble, K., Sheehan, A., Schmied, V., \& Dykes, F. (2011). Staff perceptions and experiences of implementing the Baby Friendly Initiative in neonatal intensive care units in Australia. Journal of Obstetric, Gynecologic, \& Neonatal Nursing, 40(1), 25-34. doi: 10.1111/j.1552-6909.2010.01204.x

Thomson, G., Bilson, A., \& Dykes, F. (2012). Implementing the WHO/UNICEF Baby Friendly Initiative in the community: A 'hearts and minds' approach. Midwifery, 28(2), 258-264.

Tomori, C. (2014). Nighttime breastfeeding: An American cultural dilemma. Berghahn Books.

UNICEF \& WHO. (2017). Country experiences with the Baby-Friendly Hospital Initiative: Compendium of case studies around the world. https://www.healthynewbornnetwork.org/hnncontent/uploads/BFHI_Case_Studies_FINAL_.pdf. Accessed 5 Oct 2021.

Van Esterik, P. (2006). Celebrating the Innocenti declaration on the protection, promotion and support of breastfeeding: Past achievements, present challenges and priority actions for infant and young child feeding 2nd. UNICEF Innocenti Research Centre Report.

Vasiljevic-Prodanovic, D. (2015). Corruption in health care: Victims of white coat crime in Serbia. Temida, 18(1), 97-110. https://doi.org/10.2298/tem1501097v 
2 Baby (Not So) Friendly: Implementation of the Baby-Friendly Hospital Initiative...

Dnevni list Danas. (2019, July 16). Više od 13.000 mama oštećeno Zakonom o finansijskoj podršci porodici sa decom. https://www.danas.rs/ekonomija/ vise-od-13-000-mama-osteceno-zakonom-o-finansijskoj-podrsci-porodici-sa-decom/

Walsh, A. D., Walsh, A. D., Pincombe, J., Pincombe, J., Henderson, A., \& Henderson, A. (2011). An examination of maternity staff attitudes towards implementing Baby Friendly Health Initiative (BFHI) accreditation in Australia. Maternal and Child Health Journal, 15(5), 597-609. https:// doi.org/10.1007/s10995-010-0628-1

WHO. (2017). National implementation of the Baby-friendly Hospital Initiative.

WHO/UNICEF. (2009). Baby-friendly hospital initiative: revised, updated and expanded for integrated care. https://apps. who.int/iris/handle/10665/43593. Accessed 5 Oct 2021.

Wieczorek, C. C., Schmied, H., Dorner, T. E., \& Dür, W. (2015). The bumpy road to implementing the Baby-Friendly Hospital Initiative in Austria: A qualitative study. International Breastfeeding Journal, 10(1), 3. https://doi.org/10.1186/s13006-015-0030-0

Open Access This chapter is licensed under the terms of the Creative Commons Attribution 4.0 International License (http://creativecommons.org/licenses/by/4.0/), which permits use, sharing, adaptation, distribution and reproduction in any medium or format, as long as you give appropriate credit to the original author(s) and the source, provide a link to the Creative Commons license and indicate if changes were made.

The images or other third party material in this chapter are included in the chapter's Creative Commons license, unless indicated otherwise in a credit line to the material. If material is not included in the chapter's Creative Commons license and your intended use is not permitted by statutory regulation or exceeds the permitted use, you will need to obtain permission directly from the copyright holder.

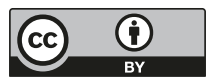

